\title{
Swiss Climate Change Law
}

\section{International and European Context}

\author{
Julia Hänni and Tienmu Ma
}

\section{Contents}

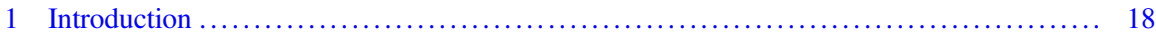

2 Switzerland and the International Climate Change Regime ......................... 19

2.1 The United Nations Framework Convention on Climate Change (UNFCCC) ...... 20

2.2 The Kyoto Protocol ............................................... 24

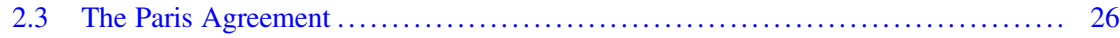

3 Swiss Climate Policy and the EU Emissions Trading System ................... 30

3.1 The $\mathrm{CO}_{2}$ Act and the Agreement on Linking the Emissions Trading Systems

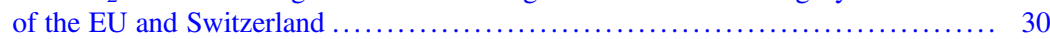

3.2 Agreement on Linking the Emissions Trading Systems of the EU and Switzerland . 32

3.3 EU ETS and the "European Green Deal" ................................. 33

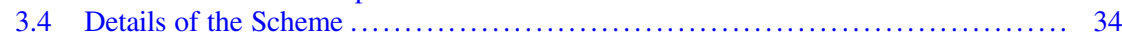

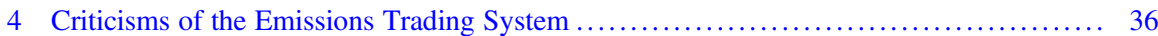

$4.1 \quad$ Far More Modest Reduction than Required ............................ 36

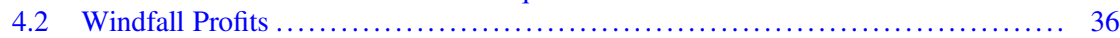

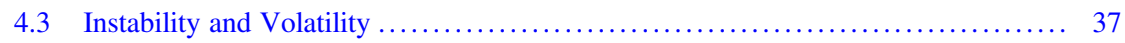

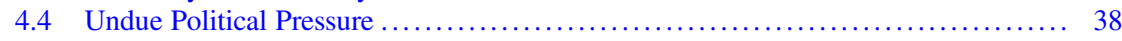

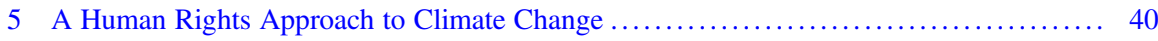

5.1 Link to the Human Rights Approach in the Paris Agreement .................. 40

5.2 Art. 2 and 8 ECHR and ECtHR Case Law .............................. 40

5.3 Landmark Judgment in The State of the Netherlands v. The Urgenda Foundation . . 41

5.4 Future Prospects of the Human Rights Approach ......................... 44

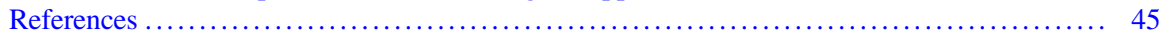

This chapter provides an overview of the state of Swiss, European, and international climate change law, up to and including January 2021 when the chapter was submitted to the publisher.

J. Hänni $(\bowtie)$

Swiss Federal Supreme Court, Lausanne, Switzerland

University of St. Gallen Law School, St. Gallen, Switzerland

e-mail: juliafranziska.haenni@unisg.ch

T. Ma

University of Lucerne Faculty of Law, Lucerne, Switzerland

e-mail: tienmu.ma@unilu.ch 


\begin{abstract}
This chapter explores the relationship between Swiss climate change law and the international and European climate change regimes. At the international level, the chapter reviews the three major international agreements regulating the field: the United Nations Framework Convention on Climate Change (UNFCCC), the Kyoto Protocol to the UNFCCC, and the Paris Agreement. And at the national and regional levels, the chapter briefly describes the $\mathrm{CO}_{2}$ Act-often considered the heart of Swiss climate change policy-and questions whether it will prove effective in achieving its explicitly stated emissions reduction targets. The chapter then reviews the most significant recent innovation in the evolution of Swiss climate change policy: joining the Emissions Trading System (ETS) established by the European Union. Due to long-standing problems afflicting the ETS, the authors raise doubts about whether Switzerland's joining the scheme will lead to meaningful reductions in the country's greenhouse gas emissions. As an alternative to an ETS-centric approach, the authors refer to an approach centered on human rights. Drawing on the jurisprudence of the European Court of Human Rights (ECtHR), the major international climate change agreements, other sources of international law, and the recent Urgenda decision of the Supreme Court of the Netherlands, the authors argue that under the human rights approach, Switzerland would be obligated to take stronger measures to reduce emissions than it could hope to achieve through the ETS and the $\mathrm{CO}_{2}$ Act alone.
\end{abstract}

\title{
1 Introduction
}

Perhaps more than in other areas, the field of climate change law involves a complex interaction among different actors at multiple levels of governance. This chapter seeks to provide an overview of how this interaction-involving actors at the national, European, and international levels - has shaped the way in which the field of climate change is regulated in Switzerland. The aim of the chapter, then, will be to explore the relationship between Swiss climate change law and the international and European climate change regimes; and a further aim will be to show how Switzerland's approach to regulating this area might be improved in light of recent developments in the field of human rights law.

The chapter is divided into four main parts. The first part (Sect. 2) presents an overview of the international climate change regime as embodied in the United Nations Framework Convention on Climate Change (UNFCCC), the Kyoto Protocol to the UNFCCC, and the Paris Agreement. Switzerland is a state party to all three agreements. The second part (Sect. 3) describes the current version of the $\mathrm{CO}_{2} \mathrm{Act}-$ often considered the heart of Swiss climate change policy-and questions whether it will prove effective in achieving its explicitly stated emissions reduction targets. Section 3 then discusses the most significant recent innovation in the evolution of Swiss climate change policy: joining the Emissions Trading System (ETS) established by the European Union. It will be argued in the third part (Sect. 4), however, that the long-standing problems afflicting the ETS raise doubts about 
whether joining the scheme will lead to meaningful reductions in Switzerland's greenhouse gas emissions. As an alternative to an ETS-centered approach, the fourth and final part of the chapter (Sect. 5) suggests the possibility of a reorientation: Drawing on the jurisprudence of the European Court of Human Rights (ECtHR), the major international climate change agreements, other sources of international law, and the recent Urgenda decision of the Supreme Court of the Netherlands, it argues that under the human rights approach, Switzerland would be obligated to take stronger measures to reduce emissions than it could hope to achieve by joining the ETS and implementing the $\mathrm{CO}_{2}$ Act.

\section{Switzerland and the International Climate Change Regime}

Switzerland does not rank as one of the main emitters of greenhouse gases in the world today: According to official data reported in 2015, it is only responsible for around $0.1 \%$ of today's global greenhouse gas emissions, which amounts to approximately 6.4 tons per capita per year. ${ }^{1}$ In spite of this, the effects of global warming are felt to a greater degree in Switzerland than in many other countries, both in terms of the raw increase in temperature and in terms of the life-threatening ramifications of that increase. Thus, according to Proclim (Akademie der Naturwissenschaften Schweiz)/IPCC Switzerland, ${ }^{2}$ the average annual temperature in Switzerland has, in the last 150 years, risen about twice as much as the global mean, with a global mean temperature increase of about $0.85{ }^{\circ} \mathrm{C}$, as compared to a mean increase of $1.8{ }^{\circ} \mathrm{C}$ in Switzerland. ${ }^{3}$ These significant rises in temperature over such a short period of time-considerably more rapid than the relatively gradual temperature changes of pre-industrial times-are suspected of causing deadly natural events, such as mudslides and landslides in mountainous areas of Switzerland. ${ }^{4}$

\footnotetext{
${ }^{1}$ See "Switzerland's intended nationally determined contribution (INDC) and clarifying information," available at the UNFCCC website at: https://www.unfccc.int.

${ }^{2}$ IPCC Switzerland, run by ProClim on behalf of the Federal Office of the Environment, aims to provide specific information on the IPCC that is relevant to Swiss researchers and stakeholders, as well as to the general public in and from Switzerland.

${ }^{3}$ See Swiss Academies of Arts and Science (2016), p. 14, summarizing national studies in Switzerland prepared for the IPCC AR5 (https://www.ipcc.ch/report/ar5). The IPCC was established by the United Nations Environment Programme (UNEP) and the World Meteorological Organization (WMO) in 1988 with the aim of providing the world with a scientific view on the current state of knowledge on climate change and its potential environmental and socio-economic impacts (https://www.ipcc.ch/about). The most recent data from the Swiss Federal Office of Meteorology and Climatology, from 2019, indicates an even larger increase of $2.1{ }^{\circ} \mathrm{C}$ in the previous 150 years. See "Climate Change in Switzerland," available at https://www.meteoswiss. admin.ch.

${ }^{4}$ See, e.g., McClanahan (2019); see also "Klimaseniorinnen reichen Klage ein", Neue Zürcher Zeitung (25 October 2016), available at https://www.nzz.ch, which describes the first climate change-related lawsuit filed in Switzerland. The lawsuit was filed by a group of elderly women
} 
Despite not being a major greenhouse gas emitter, Switzerland has reacted sensitively to the global problem of climate change. It has ratified the UNFCCC, the Kyoto Protocol, and the Paris Agreement. All of these agreements impose greater obligations and expectations on Switzerland and other developed countries than the corresponding obligations they impose on developing countries. The following three subsections review and compare the respective agreements. ${ }^{5}$

\subsection{The United Nations Framework Convention on Climate Change (UNFCCC)}

\subsubsection{Overview and Main Purpose}

The UNFCCC was opened for signature at the 1992 Rio Conference and has been in force since 1994, with 195 parties. The UNFCCC is a framework convention, in the sense that it sets the most important guidelines but does not impose any substantive targets.

According to Art. 2 of the Convention, preventing dangerous human interference with the climate system is the aim of the UNFCCC. The primary objective is "to achieve (...) stabilization of greenhouse gas concentrations in the atmosphere at a level that would prevent dangerous anthropogenic interference with the climate system. Such a level should be achieved within a time frame sufficient to allow ecosystems to adapt naturally to climate change, to ensure that food production is not threatened and to enable economic development to proceed in a sustainable manner."

\subsubsection{Main Principles}

In their actions to achieve these aims, the Parties to the UNFCCC are to be guided by four main principles (Art. 3 UNFCCC).

First, the Convention states that the Parties should "protect the climate system for the benefit of present and future generations of humankind, on the basis of equity

claiming that the Swiss government violated their human rights by failing to take adequate measures to reduce greenhouse gas emissions. According to the plaintiffs, this failure has contributed to increasingly intense and frequent heat waves in Switzerland as a result of global warming, thereby putting the plaintiffs' life and health at risk. For a comprehensive overview of the litigation, see Bär et al. (2018), p. 194. The Swiss Federal Supreme Court, First Public Law Division, dismissed the lawsuit; see the Court's judgment no. 1C_37/2019, issued on 5 May 2020. On 26 November 2020, the plaintiffs filed an application before the ECtHR, challenging the Federal Supreme Court's ruling. A copy of the application can be found at KlimaSeniorinnen Schweiz's website: https:// klimaseniorinnen.ch.

${ }^{5}$ For an overview of the UN climate treaties, see Hänni (2020), pp. 619-620, as well as Hänni (2019), pp. 3-6, for further details. 
and in accordance with their common but differentiated responsibilities. Accordingly, the developed country Parties should take the lead in combating climate change and the adverse effects thereof' (Art. 3 para. 1 UNFCCC). This distinction between the obligations of developed countries and those of all countries in addressing the problem of climate change is an example of the principle of "common but differentiated responsibilities."

Second, the UNFCCC incorporates a version of the precautionary principle, obligating state Parties to take "precautionary measures to anticipate, prevent or minimize the causes of climate change and mitigate its adverse effects" (Art. 3 para. 3 UNFCCC). ${ }^{6}$ Significantly, Article 3 also makes clear that, where there is a threat of serious or irreversible damage, the absence of full scientific certainty should not be considered a reason to postpone the precautionary measures.

Third, according to the integration principle, "The Parties have the right to, and should, promote sustainable development. Policies and measures to protect the climate system ... should be integrated with national development programmes, taking into account that economic development is essential for adopting measures to address climate change" (Art. 3 para. 4). This principle attempts to strike a careful balance between, on the one hand, the right of countries-especially developing countries - to pursue their own economic development and, on the other hand, the expectation that these countries will take steps to ensure that this development proceeds in such a fashion that it does not impede the achievement of climate protection goals.

And fourth, the principle of cooperation states that "[t]he Parties should cooperate ... to address the problems of climate change" (Art. 3 para. 5). Climate change is a global problem, and this provision recognizes that it requires a global solution, involving cooperation among all parties, with each party doing its fair share. As we shall see below, this principle gains in significance when climate change is viewed from a human rights perspective. ${ }^{7}$

The first principle-the principle of "common but differentiated responsibilities"-is perhaps the most important of the four. The principle finds expression not only in the UNFCCC but also in the Kyoto Protocol and the Paris Agreement. And it also provides a key to understanding the substantive obligations these conventions impose on developed and developing countries, respectively.

\footnotetext{
${ }^{6}$ The term mitigation refers to all efforts to reduce or prevent emission of greenhouse gases. Mitigation can mean using new technologies and renewable energies, making older equipment more energy-efficient, or changing management practices or consumer behavior (see Art. 3 para. 3; Art. 4 para. 1 subpara. b; Art. 4 para. 1 subpara. f; Art. 4 para. 2 subpara. a UNFCCC). A secondary objective of the Convention is adaptation to the change. This refers to helping communities and ecosystems cope with changing climate conditions (Art. 4 para. 1 subpara. b, Art. 4 para. 1 subpara. e and Art. 4 para. 4 UNFCCC). Examples of adaptation include the more efficient use of water resources due to climate change-induced droughts and the building of physical defenses against floods caused by rising sea levels.

${ }^{7}$ See note 68 below and Sect. 5 generally.
} 
The differing responsibilities imposed on developed and developing countries are a reflection of the fact that the former countries are the source of most past and current greenhouse gas emissions. ${ }^{8}$ Therefore, industrialized countries are expected to contribute the most to cutting emissions on home ground, in this way taking the lead in modifying anthropogenic emissions of greenhouse gases consistent with the objective of the UNFCCC (Art. 4 para. 2 subpara. a UNFCCC). These countries are called Annex I countries, which are those belonging to the Organization for Economic Cooperation and Development (OECD), including Switzerland, as well as 12 countries considered to be "economies in transition."

In line with this, Art. 4 of the Convention sets up a system of differentiated commitments applying to developed countries and developing countries respectively. For example, the industrialized countries listed in Annex I are required to adopt national policies to mitigate climate change by limiting greenhouse gas emissions through the protection and enhancement of greenhouse gas sinks and reservoirs (Art. 4 para. 2 subpara. a UNFCCC). ${ }^{9}$ The aim is to individually or jointly return to their 1990 level of anthropogenic emissions of carbon dioxide and other greenhouse gases not controlled by the Montreal Protocol (Art. 4 para. 2 subpara. b UNFCCC). However, it must be noted that the Convention does not contain any information on concrete measures, nor does it include a binding definition of the reduction target (level of 1990 until the year 2000). Concrete legal implications come only with the Protocols.

According to Art. 4 para. 2 subparas. a and b UNFCCC, industrialized countries shall individually or "jointly" return to their 1990 level of anthropogenic emissions of carbon dioxide and other greenhouse gases. The concentration of greenhouse gases in the atmosphere does not depend on where they are emitted or reduced. Industrialized states may therefore implement the required measures "together with other states," and measures can be taken where the marginal cost is the lowest. This clause has opened the Convention to criticism on the part of developing countries, as it allows the most powerful industrial states to find ways around their duties of reduction.

Annex II of the Convention deals with new financial resources. The UNFCCC directs new funds to climate change activities in developing countries as a duty of countries listed in Annex II, which is a shorter list, also including Switzerland. Thus, industrialized nations listed in Annex II agree to support climate change activities in developing countries by providing new financial support for action on climate change, above and beyond any financial assistance they already provide to these countries (Art. 4 para. 3 UNFCCC). Furthermore, a system of grants and loans has been set up through the Convention and is managed by the Global Environment

\footnotetext{
${ }^{8}$ See, e.g., Center for Global Development (2015); see also Rocha et al. (2015).

${ }^{9}$ According to Art. 1 paras. 7 and 8, respectively, a "reservoir" is defined as "a component or components of the climate system where a greenhouse gas or a precursor of a greenhouse gas is stored"; and a "sink" is defined as "any process, activity or mechanism which removes a greenhouse gas, an aerosol or a precursor of a greenhouse gas from the atmosphere."
} 
Facility (Art. 21 para. 3 UNFCCC). Developing countries are to be supported with regard to costs of adapting to the adverse effects of climate change (Art. 4 para. 4 UNFCCC). And industrialized countries agree to share environmentally sound technologies and know-how with developing countries to enable the implementation of the Convention (Art. 4 para. 3, Art. 4 para. 5, Art. 4 para. 8 UNFCCC).

Despite the more stringent duties imposed on the developed countries, the UNFCCC also imposes some duties on developing countries, such as establishing inventories of anthropogenic emissions by sources and removals by sinks, and developing and implementing national/regional programs to mitigate climate change and to communicate information related to implementation (Art. 4 para. 1 subparas. $\mathrm{a}, \mathrm{b}$ and $\mathrm{j}$ UNFCCC). ${ }^{10}$

Such duties, however, are subject to a relationship of conditionality vis-à-vis the developed countries' fulfillment of their duties. Art. 4 para. 7 UNFCCC states:

The extent to which developing country Parties will effectively implement their commitments under the Convention will depend on the effective implementation by developed country Parties of their commitments under the Convention related to financial resources and transfer of technology and will take fully into account that economic and social development and poverty eradication are the first and overriding priorities of the developing country Parties.

\subsubsection{Conference of the Parties}

The Conference of the Parties (COP) is the supreme body of the Convention, as provided for by Art. 7 UNFCCC. The COP is charged with the following responsibilities:

- regular review of the implementation of the convention, that is, periodic examination of the Parties' obligations (Art. 7 para. 2 let a UNFCCC);

- providing and facilitating exchange of information on measures adopted by the Parties to address climate change (Art. 7 para. 2 subpara. b UNFCCC);

- making recommendations on matters necessary for implementation (Art. 7 para. 2 subpara. g UNFCCC).

Ordinary COPs are to be held every year (Art. 7 para. 4 UNFCCC). All states that are Parties to the Convention are represented at COP meetings, and the admission of observers (agencies of the UN, NGOs) is also possible. Meetings of the COP are

\footnotetext{
${ }^{10}$ For example, the Fourth National Communication of Mexico to the United Nations Framework Convention on Climate Change (Mexican Interministerial Commission on Climate Change [2011]) describes updates to its National Greenhouse Gas Inventory (pp. 55-103) as well as various efforts at mitigation and adaptation, such as a National Water Program that aims "to reduce the risks associated with meteorological and hydrometeorological extremes and address their impacts" (p. 116). Switzerland's greenhouse gas inventory is available at the website of the Federal Office for the Environment, https://www.bafu.admin.ch.
} 
numbered in the order in which they are held. For example, "COP 13" represents the thirteenth Conference of the Parties.

The COP also has the power to adopt related legal instruments. Thus, "the Conference of the Parties may, at any ordinary session, adopt protocols to the Convention" (Art. 17 para. 1 UNFCCC). Protocols ${ }^{11}$ can contain regulations concerning specific air pollutants or groups of air pollutants as well as provisions on concrete quantitative reduction targets. The most important related instruments are the Kyoto Protocol to the UNFCCC (Kyoto Protocol) and recently the Paris Agreement.

\subsection{The Kyoto Protocol}

\subsubsection{Overview}

The first meeting of the Conference of the Parties (COP 1) took place in Berlin in 1995. There, the Parties agreed to produce a Protocol containing quantitative measures and reduction targets. Two years later, COP 3 in Kyoto adopted a Protocol to the UNFCCC, containing legally binding reduction targets and imposing time limits on industrialized states concerning greenhouse gases (Art. 3 in conjunction with Annexes A and B Kyoto Protocol). The Protocol entered into force on 16 February 2005.

Recognizing again that developed countries are principally responsible for the current high levels of greenhouse gas emissions in the atmosphere as a result of more than 150 years of industrial activity, the Protocol places a heavier burden on developed nations under the aforementioned principle of "common but differentiated responsibilities." The Kyoto Protocol currently has 192 Parties, including Switzerland. $^{12}$ The negotiations were difficult, and some major countries have still not become parties to the Protocol, including the United States and Canada.

\subsubsection{Emission Reduction Mechanisms}

\section{Art. 3 para. 1 of the Protocol states:}

The Parties included in Annex I shall, individually or jointly, ensure that their aggregate anthropogenic carbon dioxide equivalent emissions of the greenhouse gases listed in Annex A do not exceed their assigned amounts, calculated pursuant to their quantified emission limitation and reduction commitments inscribed in Annex B and in accordance with the

\footnotetext{
${ }^{11}$ This is not to be confused with the Montreal Protocol of 1987, whose aim was to protect the ozone layer from depletion (SR 0.814.021).

${ }^{12}$ See the Kyoto Protocol's status of ratification, available at: https://unfccc.int/process/the-kyotoprotocol/status-of-ratification.
} 
provisions of this Article, with a view to reducing their overall emissions of such gases by at least 5 per cent below 1990 levels in the commitment period 2008 to 2012.

States listed in UNFCCC Annex I must therefore individually or jointly ensure that they do not exceed the emission limitations listed in Annex B of the Kyoto Protocol. The industrialized states listed in UNFCCC Annex I are required to achieve different quantitative reduction targets listed in the Kyoto Protocol's Annex B in order to achieve the aim of the Protocol.

According to Art. 2 para. 1 subpara. a of the Protocol, industrialized states must develop and implement national measures to reduce $\mathrm{CO}_{2}$ emissions, adopting policies of energy efficiency, reforestation, and sustainable agriculture, and to phase out fiscal incentives, tax exemptions, and subsidies that run counter to the aims of the UNFCCC and the Kyoto Protocol.

But the Protocol also offers additional means to meet emission reduction targets. These include joint implementation and fulfillment, the Clean Development Mechanism, and international emissions trading.

Art. 3 para. 10 and Art. 3 para. 11 of the Protocol, in conjunction with Art. 6, foresee joint implementation, allowing states listed in UNFCCC Annex I to transfer emission reduction units to other states listed in Annex I. When financing emission reductions in another state, the respective emission reduction units are attributable to their own reduction targets.

The Protocol also provides for joint fulfillment. According to Art. 3 para. 1, in conjunction with Art. 4 of the Protocol, states can meet reduction targets in groups (the sum of individual reduction targets can be met by the whole group of states), e.g., the countries of the European Union.

The Kyoto Protocol's Clean Development Mechanism is delineated in Art. 12. It allows a country with an emission reduction or emission limitation commitment (Annex B country) to implement an emission reduction project in a developing country. Such projects can earn saleable certified emission reduction credits, which can then be counted towards meeting the Protocol's targets.

The Clean Development Mechanism represents the first global environmental investment and credit scheme of its kind. It might involve, for example, a rural electrification project using solar panels or the installation of more energy-efficient boilers. The mechanism stimulates sustainable development and emission reductions, while giving industrialized countries some flexibility in meeting their emission reduction or limitation targets.

\subsubsection{Emissions Trading}

As indicated above, another major innovation of the Kyoto Protocol is emissions trading, covered under Art. 17: "The Parties included in Annex B [industrialized states] may participate in emissions trading for the purposes of fulfilling their commitments under Art. 3 [compliance with their reduction targets]." 
Emissions trading allows countries that have emission units to spare-i.e., permitted emissions left unused - to sell this excess capacity to countries that are over their targets. Art. 17 rests on two main premises: (1) emissions trading is open to states subject to the commitments in Annex B; and (2) trading must be supplemental to domestic actions. Since carbon dioxide is the principal greenhouse gas, emissions trading is often referred to as the "carbon market."

\subsection{The Paris Agreement}

\subsubsection{Overview}

In terms of effectiveness, the Kyoto Protocol had the advantage of a top-down prescriptive nature, as well as an implementation clause. However, in the end it proved not to be as effective as initially hoped. This is in large part due to the fact that, as noted above, it has failed to gain the support of some of the countries that contribute the most to worldwide greenhouse gas emissions.

In December 2015, the 21st Conference of the Parties to the UNFCCC adopted the "Paris Agreement," a new collective treaty to fight anthropogenic climate change. The Agreement is an instrument linked to the UNFCCC. After 25 years of UN climate diplomacy, the Paris Agreement was the first treaty to envisage climate action by all nations. Notably, the Agreement's preamble makes an explicit link between climate change and the fulfillment of human rights obligations. ${ }^{13}$

\subsubsection{The $2{ }^{\circ} \mathrm{C}$ Limit}

Article 2 of the Paris Agreement proposes some ambitious objectives. The long-term goal of the Agreement is to keep global temperature rise "well below $2^{\circ} \mathrm{C}$ " (Art. 2 Paris Agreement). This is a strengthened goal in comparison with earlier language. According to recent science (IPCC), the $2{ }^{\circ} \mathrm{C}$ limit would probably-though not certainly - prevent the most severe effects of climate change. Article 2 also contains the aim to "pursu[e] efforts to limit the temperature increase to $1.5^{\circ} \mathrm{C}$ above pre-industrial levels", as proposed by small island states and least developed countries. This will be a challenge, especially for countries that have yet to lift the majority of their citizens from poverty.

\footnotetext{
${ }^{13}$ See Preamble para. 11 Paris Agreement: "Acknowledging that climate change is a common concern of humankind, Parties should, when taking action to address climate change, respect, promote and consider their respective obligations on human rights, the right to health, the rights of indigenous peoples, local communities, migrants, children, persons with disabilities and people in vulnerable situations and the right to development, as well as gender equality, empowerment of women and intergenerational equity."
} 
How, then, can the "well below $2^{\circ} \mathrm{C}$ " goal be reached? First, Parties aim to reach "global peaking of greenhouse gas emissions as soon as possible" (Art. 4 para. 1 Paris Agreement). However, no peaking dates and no percentage reductions are mentioned, recognizing that peaking will take longer for developing countries. Second, rapid reductions are foreseen thereafter: achieving a balance between anthropogenic emissions by reducing the emission of greenhouse gases during the second half of the century (Art. 4 para. 1, Art. 5 para. 1 Paris Agreement). Third, Parties shall formulate and implement long-term low greenhouse gas emission development strategies (Art. 4 para. 19 Paris Agreement). And fourth, stronger mitigation is provided for through so-called Nationally Determined Contributions (NDCs; Art. 3 Paris Agreement).

\subsubsection{Nationally Determined Contributions}

Let us take a closer look at this last mechanism, the Nationally Determined Contributions (NDCs). The Paris Agreement states that "[e]ach Party shall prepare, communicate and maintain successive nationally determined contributions that it intends to achieve. Parties shall pursue domestic mitigation measures, with the aim of achieving the objectives of such contributions" (Art. 4 para. 2 Paris Agreement). The Agreement contains no binding concrete contribution-only an expectation. It is, however, binding in the sense of an obligation of conduct in good faith (Parties are required to "prepare," "intend to achieve," etc.). ${ }^{14}$ The NDC scheme therefore represents a "bottom-up approach," unlike its predecessor, the Kyoto Protocol.

According to the Agreement, developed countries should continue to take the lead by undertaking an "absolute emission reduction target"; developing countries are to continue enhancing mitigation (Art. 4 para. 2, Art. 4 para. 4 Paris Agreement).

Furthermore, each successive NDC is to represent a progression beyond the previous and to reflect the "highest possible ambition." This means that adjustment of the contributions is possible only in the direction of enhancing the level of ambition (see Art. 4 para. 3 Paris Agreement; "ambition" or "ratchet mechanism"). But again, the "highest possible ambition" is left to national determination. The efforts of all Parties are to represent a progression over time (Art. 3 Paris Agreement; collective requirement).

\subsubsection{International Linkage and Adaptation}

Article 6 of the Paris Agreement provides for a Sustainable Development Mechanism. International linkage under this provision gives the Parties a "green light" to develop carbon markets to promote the mitigation of greenhouse gas emissions while fostering sustainable development. Thus, similar to the Kyoto Protocol,

${ }^{14}$ See Hänni (2019), p. 4, for a detailed discussion. 
emission reductions occurring outside of a Party's territory can be counted toward achieving the Party's Nationally Determined Contribution (Art. 6 para. 4 subpara. c Paris Agreement). This enables both the formation of coalitions and bottom-up heterogeneous linkage. ${ }^{15}$ Different forms of emissions trading, explicitly provided for in the Kyoto Protocol, are therefore also possible under the Paris Agreement.

Article 7 of the Paris Agreement deals with mechanisms for adaptation, that is, instruments for dealing with the inevitable effects of climate change. The Paris Agreement establishes a global goal on adaptation, including through support for and international cooperation on adaptation efforts (Art. 7 paras. 1 and 6 Paris Agreement). Developing country Parties will receive enhanced support for adaptation actions (Art. 7 para. 7 Paris Agreement). All Parties are expected to engage in adaptation planning and to submit and periodically update an adaptation communication on their priorities, implementation and support needs, plans and actions (Art. 7 para. 10 Paris Agreement).

\subsubsection{Loss and Damage and Global Stocktake}

Article 8 of the Paris Agreement, concerning loss and damage, provides for yet another mechanism for climate action, in addition to mitigation and adaptation. Thus, the Paris Agreement builds on the Warsaw International Mechanism by providing for formal recognition and comprehensive risk management approaches to address loss and damage associated with the adverse effects of climate change. This new mechanism has not, however, been fully developed and will have to be concretized by future COPs in order to serve as an effective basis for compensation. Most recently, the mechanism was subject to intense negotiations at COP 25, where a key sticking point was the issue of how to finance the mechanism. There was consensus among the Parties that financing to avert, minimize, and address loss and damage must be "scaled up." "16 But the Parties could not come to an agreement to obligate developed countries in particular to fund this scaling up. ${ }^{17}$

\footnotetext{
${ }^{15}$ There are three relevant types of heterogeneity. First, there may be heterogeneity of policy instruments: It is possible not only to link two cap-and-trade systems, for example, but also a cap-and-trade system and a carbon tax system. Second, there may be heterogeneity in the formulation of the countries' respective NDCs themselves: Some NDCs, for example, might specify an aggregate emissions cap, while others might have only a cap on emissions per unit of economic activity. And third, there may be heterogeneity of jurisdiction: The systems to be linked can exist at regional, national, or sub-national jurisdictions. The agreement linking the EU and Switzerland's respective emissions trading systems (see Sect. 3 below) is an example of this kind of heterogeneity. The various types of heterogeneity are explained in Stavins (2016), pp. 54-55.

${ }^{16}$ See Decision 2/CMA.2, Warsaw International Mechanism for Loss and Damage associated with Climate Change Impacts and its 2019 review, §§ 30, 32, 33, and 35.

${ }^{17}$ For an account of the negotiations, see Pierre-Nathoniel, Siegele, et al., "Loss and Damage at COP25 - a hard fought step in the right direction," The Climate Analytics Blog (20 December 2019), available at: https://climateanalytics.org.
} 
The Paris Agreement also provides that each Party is to report information on mitigation, adaptation, and support; the agreement requires that the information submitted by each Party undergo international review. A "global stocktake" is slated to take place in 2023 and every 5 years thereafter to assess collective progress toward fulfilling the purpose of the agreement (Art. 14 Paris Agreement). The outcomes of the stocktake will inform Parties in updating and enhancing their own national actions as well as international cooperation.

In 2018, a facilitative dialogue took place in order to encourage collective progress towards the long-term emission reduction goal of Art. 4 Paris Agreement. The dialogue was officially named the "Talanoa Dialogue," inspired by the Fijian tradition of dialogue in an inclusive and participatory manner. The dialogue culminated in the "Talanoa Call for Action" issued jointly by the Presidents of COP 23 and COP 24. The call was directed towards a wide range of actors and stakeholders, including state institutions, the private sector, and civil society, reiterating the goal of the Paris Agreement "to hold temperature rise well below 2 degrees Celsius and to pursue efforts to limit it to 1.5 degrees." 18

\subsubsection{Assessment of the Paris Agreement as Compared to Its Predecessors}

The Paris Agreement is distinctive in a number of ways as compared to its two predecessors, the UNFCCC and the Kyoto Protocol. The guiding principles stated in the UNFCCC are put into more or less concrete form in the Paris Agreement. But unlike the Kyoto Protocol, the Paris Agreement does not take a top-down, prescriptive approach - an approach that, as noted above, has thus far proved politically unsuccessful in gaining the support of some of the world's most important countries in terms of greenhouse gas emissions, though it remains to be seen whether this will change in the future. ${ }^{19}$ The Paris Agreement instead takes a bottom-up facilitative approach $^{20}$ as a starting point, with national contributions constituting the bottom, and with rules of transparency, reporting, and so on constituting the top elements. ${ }^{21}$ The Paris Agreement represents a facilitative rather than a prescriptive instrument. It tries to find a balance between, on the one hand, ensuring autonomy for states in the determination of their contributions and, on the other hand, strengthening oversight

\footnotetext{
${ }^{18}$ See the "Talanoa Call for Action," available at https://unfccc.int.

${ }^{19}$ It should be noted, however, that the Paris Agreement has also run into difficulties in this respect: It lost the support of the United States during the Trump Administration, which filed a formal withdrawal notice on 4 November 2019. The withdrawal took effect one year later, in accordance with Art. 28 para. 2 Paris Agreement. The United States' withdrawal ended up being a temporary one: On his first day in office, President Biden signed an executive order rejoining the Paris Agreement. See Milman, "Biden returns US to Paris climate accord hours after becoming president," The Guardian (21 January 2021), available at https://www.theguardian.com.

${ }^{20}$ This term is also used in Dehm (2018), p. 74.

${ }^{21}$ On the combination of bottom-up and top-down elements, see also Rajamani (2016), p. 502.
} 
of these contributions through a robust transparency system, a global stocktake process (leading to the incremental adjustment of Nationally Determined Contributions in service of the long-term goals), and a compliance mechanism. However, the Agreement leaves mechanisms to be finalized by the Parties. And there are no clear and specific goals in relation to finance, technology and capacity-building. ${ }^{22}$

\section{Swiss Climate Policy and the EU Emissions Trading System}

\subsection{The $\mathrm{CO}_{2}$ Act and the Agreement on Linking the Emissions Trading Systems of the EU and Switzerland}

The heart of Swiss climate policy is commonly considered to be the Federal Act on the Reduction of $\mathrm{CO}_{2}$ Emissions, or simply the $\mathrm{CO}_{2}$ Act. The current version of the Act, of 23 December 2011, entered into force on 1 January 2013 and has been subjected to occasional revisions in the interim, ${ }^{23}$ whereas a new version of the Act, of 25 September 2020, has been approved by the Parliament but has yet to enter into force, pending the results of a popular referendum. ${ }^{24}$

The aim of the Act, stated in Article 1, is to reduce greenhouse gas emissions and in particular $\mathrm{CO}_{2}$ emissions resulting from the use of fossil fuels in energy. Echoing Article 2 of the Paris Agreement, the Act aims to contribute to limiting the increase in global temperatures to well below $2{ }^{\circ} \mathrm{C}$ compared to pre-industrial levels and to contribute to efforts to limit that increase to below $1.5^{\circ} \mathrm{C}$.

More specifically, Article 3 of the Act also stipulates concrete emission reduction goals for Switzerland: a target of $50 \%$ in emission reduction compared to 1990 levels, by 2030 , with a $35 \%$ reduction over the period of 2021-2030. It is worth noting that, in addition to these statutory aims, the Federal Council has set an even more ambitious post-2030 goal: net-zero emissions by 2050 . This commitment has

\footnotetext{
${ }^{22}$ As noted by Arens et al. (2015), p. 4: "The Paris Agreement only contains vague language concerning concrete financing contributions for mitigation and adaptation in developing countries. Legal bindingness of financing contributions in the Paris Agreement has been sacrificed due to pressure by the USA."

${ }^{23}$ Bundesgesetz, über die Reduktion der $\mathrm{CO}_{2}$-Emissionen (CO ${ }_{2}$-Gesetz; SR 641.71) vom 11. Dezember 2011.

${ }^{24}$ Bundesgesetz über die Verminderung von Treibhausgasemissionen ( $\mathrm{CO}_{2}$-Gesetz) vom 25. September 2020. Unless otherwise stated, references to the Act will henceforth be to this, the latest version. Regarding the popular referendum, see "Climate and Covid laws set to come to public vote," SWI Swissinfo.ch (12 January 2021), available at https://www.swissinfo.ch. As the article notes, opponents of the law appear to have gathered more than enough signatures to force a referendum, but this has yet to be officially confirmed.
} 
been confirmed in Switzerland's official communication to the UNFCCC under the Paris Agreement. ${ }^{25}$

That the $\mathrm{CO}_{2}$ Act is considered the heart of Swiss climate policy is affirmed in its own text, which states that the aforementioned emission reduction target is to be achieved primarily through the Act's provisions (Art. 4 para. 1). One of the central instruments for the achievement of that target is the $\mathrm{CO}_{2}$ levy, which imposes a tax on the production, extraction, and import of thermal fuels (Art. 34-41). The resultant increase in the price of fossil fuels creates an incentive to use them more economically, as well as to choose more low-carbon energy sources. And in a major revision of the previous version of the Act, the latest version adds a tax to be imposed on airline tickets and on aviation operations generally (Art. 42-52).

Furthermore, the Act aims to contribute to the reduction of emissions through the improvement of building standards (Art. 9-10) and the imposition of more stringent limits on vehicle emissions (Art. 11-20). Article 19 of the Act provides for fines on vehicle manufacturers that fail to abide by these limits.

In line with the flexible mechanisms of the Kyoto Protocol-specifically, the aforementioned Clean Development Mechanism and joint implementation - the Act allows for emission reductions achieved abroad to count toward the overall emission target (Art. 5), though it stipulates that $75 \%$ of the reductions must come by way of measures undertaken in Switzerland (Art. 3 para. 2). Notably, however, the Act does nothing to address emissions in the agricultural sector, which is responsible for $12.9 \%$ of Switzerland's overall emissions, according to recent data. ${ }^{26}$

The Act foresees an emissions trading system (Art. 21-33). Companies in specific categories that operate installations with high greenhouse gas emissions are required to participate in the scheme (Art. 21), as well as operators of aircraft taking off from or landing in Switzerland (Art. 22). The permits are allocated to the companies free of charge to the extent that the emissions are necessary for greenhouse gas-efficient production, whereas further permits are auctioned (Art. 26). Each year, companies must surrender emission permits or emission reduction certificates equal to the emissions caused (Art. 21 para. 2). The Federal Council determines in advance the quantity of emission permits available each year until 2030, taking into account comparable international regulations (Art. 25 para. 1). For emissions that exceed the permits, companies must pay $220 \mathrm{CHF}$ per tonne $\mathrm{CO}_{2}$ equivalent $\left(\mathrm{CO}_{2} \mathrm{eq}\right)$, and the missing emission permits must be surrendered to the Confederation in the following year (Art. 29).

The Act also establishes a special Climate Fund based on the proceeds raised from the $\mathrm{CO}_{2}$ levy, the airline and general aviation taxes, the auctions of emission permits, and the penalties paid by vehicle manufacturers failing to abide by vehicle emissions limits (Art. 53-61). The Act specifies how these proceeds are to be spent,

\footnotetext{
${ }^{25}$ See "Communication and update on Switzerland's NDC in accordance with UNFCCC decision $1 /$ CP. $21, \S 24-25$ " (submitted in 2020, reaffirming the $50 \%$ reduction goal by 2030 and declaring a new goal of net-zero emissions by 2050), available at https://www.unfccc.int.

${ }^{26}$ See Federal Office of the Environment (2020), p. 282.
} 
such as for initiatives aimed at further reduction of greenhouse gas emissions or at the prevention of damage to persons or property as a result of climate change (Art. 53 para. 2 and Art. 53 para. 3).

As noted above, the version of the $\mathrm{CO}_{2}$ Act currently in force has been in place since 2013. Its effectiveness, however, has been called into serious question. The Act had set a national target of a 20\% emissions reduction, compared to 1990 levels, by 2020 (Art. 3). But according to current projections, Switzerland has probably fallen short of that goal: The Federal Office of the Environment has reported that the reduction in emissions from the base year 1990 until 2018 was only 14\%; it thus deems the 2020 goal unlikely to be achieved and declares the current evolutionary trend to be "unsatisfactory." 27 There is also reason to worry that Switzerland will miss the even more ambitious 50\% reduction target set by the new $\mathrm{CO}_{2}$ Act for the year 2030. At least one independent analysis predicts that, even on the assumption that the new version of the Act is approved by the popular referendum, enters into force, and is fully implemented, the country would only manage a $37.5 \%$ emissions reduction compared to 1990 levels. $^{28}$

\subsection{Agreement on Linking the Emissions Trading Systems of the EU and Switzerland}

As noted above, the emissions trading system is one of the main mitigation measures foreseen by the $\mathrm{CO}_{2}$ Act. Recently, Switzerland has taken a major step toward linking that system with the European Union's parallel scheme. Along these lines, the "Agreement between the European Union and the Swiss Confederation on the linking of their greenhouse gas emissions trading systems" was ratified, and it entered into force on 1 January $2020 .{ }^{29}$ The effect of the agreement is that companies in the Swiss scheme are now permitted to trade on the EU ETS market.

\footnotetext{
${ }^{27}$ Federal Office for the Environment, "Climate: Indicators," available at: https://www.bafu. admin.ch.

${ }^{28}$ Climate Action Tracker, Country Summary: Switzerland (30 November 2020); see section entitled "Current Policy Projections," available at: https://climateactiontracker.org/countries/ switzerland.

${ }^{29}$ Abkommen zwischen der Schweizerischen Eidgenossenschaft und der Europäischen Union zur Verknüpfung ihrer jeweiligen Systeme für den Handel mit Treibhausgasemissionen, SR 0.814.011.268.
} 


\subsection{EU ETS and the "European Green Deal"}

Let us take a more detailed look at the EU Emissions Trading System. The ETS is a regional realization of emissions trading as foreseen in Article 17 of the Kyoto Protocol and Article 6 of the Paris Agreement.

The point of departure of the emissions trading system is to ask: What if pollution had a financial price? The "cap and trade system" created by economists has three main elements. First, authorities limit the amount of $\mathrm{CO}_{2}$ emissions that industries are allowed to produce; this is the "cap." Permits to pollute are then distributed to companies; if a company emits more than its limit, it is required to pay a fine, thereby creating an incentive to find cleaner ways of operating. Finally, if a company emits less than it is permitted to, it can sell its permission to other companies; this is the "trade."

Every year the total number of permits is reduced; there is thus a "declining cap," entailing that it will become increasingly expensive to pollute.

In 2005, the EU introduced the world's biggest carbon trading system to date. The system represents the European Union's main effort at reducing overall emissions. The legal basis of the system is Directive 2003/87/EC of the European Parliament and of the Council of 13 October 2003 establishing a scheme for greenhouse gas emission allowance trading within the Community and amending Council Directive 96/61/EC.

The Directive adopts the market-based approach characteristic of cap-and-trade systems: Emitters operate under a declining emission cap and $\mathrm{CO}_{2}$ is priced. The aim is to generate financial incentives to reduce greenhouse gas emissions. The ETS limits emissions from power stations, industrial plants, and airlines, encompassing more than 11,000 such entities, which together comprise nearly half of the EU's $\mathrm{CO}_{2}$ emissions.

Heavy $\mathrm{CO}_{2}$ emitting companies in the EU receive emission permits ("cap"), with each permit granting the holder the right to emit one ton of $\mathrm{CO}_{2}$ or the equivalent amount of two more powerful greenhouse gases, nitrous oxide $\left(\mathrm{N}_{2} \mathrm{O}\right)$ and perfluorocarbons (PFCs).

At the end of each year a company must surrender enough allowances to cover all of its emissions; otherwise, fines are imposed. If a company reduces its emissions, it can keep the spare permits to cover its future needs or sell them to another company that is short on permits ("trade"). Like Switzerland, the EU has set ambitious goals for emission reduction: The European Commission has proposed a minimum 55\% reduction in emissions by 2030 as compared to 1990 levels 
and no net emissions by $2050 .{ }^{30}$ The ETS remains the centerpiece of the EU's effort to achieve these goals; and indeed, the Commission foresees an expanded role for the ETS going forward. ${ }^{31}$

\subsection{Details of the Scheme}

The EU ETS covers the following gases and sectors:

(1) Carbon dioxide $\left(\mathrm{CO}_{2}\right)$ from power and heat generation; energy-intensive industry sectors including oil refineries, steel works and production of iron, aluminum, metals, cement, lime, glass, ceramics, pulp, paper, cardboard, acids; and commercial aviation;

(2) Nitrous oxide $\left(\mathrm{N}_{2} \mathrm{O}\right)$ from production of nitric, adipic and glyoxylic acids and glyoxal (production of nylon, fertilizers, disinfectants, antibiotics etc.);

(3) Perfluorocarbons (PFCs) from aluminum production.

The EU ETS has proceeded thus far in three phases. The first phase, described as the "learning-by-doing" phase, began on 1 January 2005 and ended on 31 December 2007. Among the key features of Phase 1 were: $^{32}$

(1) It covered only $\mathrm{CO}_{2}$ emissions from power generators and energy-intensive industries.

(2) Almost all allowances were given to businesses for free.

(3) The penalty for non-compliance was $40 €$ per ton.

Phase 2 of the EU ETS overlapped with the first commitment period of the Kyoto Protocol, which had set concrete reduction targets for state Parties. The European Commission identifies the following key features of Phase 2 of the EU ETS:

(1) There was a lower cap on allowances (approximately 6.5\% lower compared to Phase 1).

(2) Iceland, Liechtenstein, and Norway joined the scheme.

(3) Nitrous oxide emissions from nitric acid production were included by some countries in the scheme.

(4) Free allocation of allowances fell to $90 \%$.

(5) Several countries held auctions of allowances.

(6) The non-compliance penalty was increased to $100 €$ per ton.

(7) Businesses were permitted to buy international credits amounting to approximately 1.4 billion tons of $\mathrm{CO}_{2}$-equivalent.

\footnotetext{
${ }^{30}$ See European Commission (2020).

${ }^{31}$ European Commission (2020), pp. 13-16.

${ }^{32}$ These are the key features of Phase 1, as identified by the European Commission. See "Phases 1 and 2 (2005-2012)," (https://ec.europa.eu/clima/policies/ets/pre2013_en\#tab-0-0).
} 
(8) A Union-wide registry replaced national registries and the European Union Transaction Log replaced the Community Independent Transaction Log.

(9) The aviation sector was brought into the ETS on 1 January $2012 .{ }^{33}$

Phase 3 of the EU ETS ran from 2013 to 2020. The European Commission has pointed to four main changes from the previous two phases:

(1) A single, EU-level cap has been imposed in place of the previous national caps.

(2) Auctioning has replaced free allocation as the default method of allocating allowances, and a unified set of rules now governs allowances that are distributed for free.

(3) More sectors and gases have been included.

(4) 300 million allowances have been set aside in the New Entrants Reserve to fund the deployment of innovative, renewable energy technologies and carbon capture and storage. ${ }^{34}$

The current phase of the ETS, Phase 4, is expected to run from 2021 to 2030. In order to achieve even a $40 \%$ reduction in emissions compared to 1990 levelswhich is significantly lower than the European Commission's proposed 55\% reduction ambition noted above- the Commission calculates that the sectors included in the EU ETS would have to reduce their emissions by $43 \%$ compared to 2005 levels. $^{35}$

With this target in mind, the Commission plans to implement a number of revisions to the scheme. Among the key revisions are:

(1) Increasing the pace of annual reductions in allowances to $2.2 \%$ as of 2021 ;

(2) Strengthening the Market Stability Reserve; 36

(3) Continuing the free allocation of allowances to ensure the competitiveness of industrial sectors, while at the same time ensuring that free-allocation rules are in line with technological progress;

(4) Aiding industries and the power sectors with low-carbon funding measures. ${ }^{37}$

\footnotetext{
${ }^{33}$ These are the key features of Phase 2, as identified by the European Commission, in "Phases 1 and 2 (2005-2012)."

${ }^{34}$ These features are the key features identified by the European Commission in its description of the EU ETS (https://ec.europa.eu/clima/policies/ets_en).

${ }^{35}$ See "Revision for phase 4 (2021-2030)" (https://ec.europa.eu/clima/policies/ets/revision_en).

${ }^{36}$ The Market Stability Reserve is a mechanism that began operating near the end of Phase 3, in January 2019, with the aim of reducing the allowances surplus in the carbon market and improving the scheme's resilience to future shocks. See "Market Stability Reserve" at the European Commission's Climate Action website (https://ec.europa.eu/clima/policies/ets/reform_en). The mechanism is described in further detail in Sect. 4.3 below.

${ }^{37}$ These key features of Phase 4 are identified on the Commission's Climate Action website, "Revision for phase 4 (2021-2030)."
} 


\title{
4 Criticisms of the Emissions Trading System
}

\subsection{Far More Modest Reduction than Required}

The ETS is the EU's flagship emissions reduction scheme, in operation for the past 15 years. As noted above, the fourth phase of the scheme, running from 2021-2030, has already begun. And yet, critics of the scheme have raised significant doubts about its success and viability.

The most important criticism is that the ETS has failed to reduce the EU's greenhouse gas emissions anywhere near the levels that were hoped for or that are required under international climate change conventions, such as the Kyoto Protocol's requirement that developed Annex I countries reduce their overall emissions of such gases by at least 5\% below 1990 levels. In this respect, the results of Phase 1 of the scheme were disappointing. Rather than achieving a reduction in emissions, the aggregate emissions data for participating countries actually showed a slight increase, from 2034 billion tons of $\mathrm{CO}_{2}$ in 2006 to 2050 billion tons in $2007 .{ }^{38}$ Even on an optimistic recent scientific assessment covering the period 2008-2016, the EU's scheme has led to only a $3.8 \%$ greater reduction in emissions than if the scheme did not exist at all. ${ }^{39}$ This is a far more modest reduction than is necessary to meet EU countries' obligations already under the Kyoto Protocol. It is also far more modest than both Switzerland's and the EU's ambitious plans for a $50 \%$ or $55 \%$ reduction in emissions by 2030 compared to 1990 levels and net-zero emissions by 2050 .

\subsection{Windfall Profits}

Another significant criticism is that the ETS allows energy companies to generate windfall profits due to the allocation of allowances. This calls into question the fundamental fairness of the carbon-trading scheme, which is also compounded by the problem of increased energy costs for consumers. A study by Matthew Sinclair, Research Director of the UK's Taxpayer Alliance, explains the problem as follows:

\begin{abstract}
Allowances are given to the firms for free but they are scarce and have a value, as can be seen from the price in the carbon market. That means that, whether firms are buying the allowances in the market or using those they have been freely allocated, the need to hold them pushes up the cost of production relative to not producing and selling the allowance or not buying it in the first place. Increasing the opportunity costs of production increases the price those firms charge consumers. ${ }^{40}$
\end{abstract}

There is thus a double unfairness at work here: On the one hand, by receiving the allowances for free and having the opportunity to sell them to the market, the

\footnotetext{
${ }^{38}$ European Commission (2008), p. 2.

${ }^{39}$ Bayer and Aklin (2020), p. 117.

${ }^{40}$ Sinclair (2009), p. 11. On this point, see also Ellerman and Joskow (2008), pp. 24-26.
} 
companies in question are able to secure windfall profits and are therefore unfairly advantaged; and on the other hand, consumers are unfairly required to pay increased prices due to the energy companies' having the opportunity to trade the freely allocated permits.

An important question raised by this issue is whether European judicial institutions - and the European Court of Justice (ECJ) in particular-can adapt to the challenges posed by the ETS or at least allow EU countries sufficient leeway to address such challenges themselves.

The ECJ has ruled on the effort of at least one EU country, Slovakia, to deal with the problem of windfall profits. Slovakia had decided, in 2011, to tax emission allowances (allocated free of charge) which had been sold or which had not been used at $80 \%$ of their value. The question presented in the case was whether Slovakia's actions were in conformity with the EU ETS (Directive 2003/87/EC).

The ECJ's judgment, issued on 12 April 2018 (C-302/17, PPC Power a.s.), answered this question in the negative. According to the Court, states are not permitted to undermine the objectives of the Directive 2003/87/EC. The ETS aims to encourage enterprises to reduce their greenhouse gas emissions, specifically by allowing them to trade the emission allowances they do not need. A tax of $80 \%$ on these allowances eliminates nearly all of their economic value, which would upset the delicate balance of incentives that the ETS is meant to create. The result of this judgment, however, is that national governments are prevented from addressing the problem of windfall profits that has been created by the ETS. This case provides an indication that the ECJ may not be so willing to allow the necessary flexibility in the operation of the ETS to address some of its most significant problems.

\subsection{Instability and Volatility}

Another common criticism is that the price of emission allowances has been subject to significant instability and volatility. As Ellerman et al. explain in a review article of the first two phases of the ETS, the first 10 years of the scheme saw extreme fluctuations in the price of emissions allowances, ranging from a few Euro cents to almost EUR 30. ${ }^{41}$

The problem with such price volatility is that it undermines the incentives that the ETS provides to companies to invest in emission reduction technologies. In general, the environmental effectiveness of an emissions trading scheme depends on the ability of the scheme and its regulations to provide consistent and stable incentives for companies to invest in such technologies. With highly volatile prices, however, "no clear investment signal is provided and hence firms' decision-making and planning is rendered difficult." 42 By undermining incentives to invest in clean

\footnotetext{
${ }^{41}$ Ellerman et al. (2016), pp. 96-97.

${ }^{42} \mathrm{Köppl} \mathrm{et} \mathrm{al.} \mathrm{(2011),} \mathrm{p.} 3$.
} 
energy technologies, price fluctuations therefore end up undermining the very goal of the ETS, namely that of the reduction of emissions.

In order to address the problem of instability and volatility, in January 2019 a so-called "Market Stability Reserve" (MSR) began operating within the ETS. The idea underlying the MSR is a simple one: When the number of allowances in circulation exceeds a specified upper limit, the mechanism automatically withdraws allowances and stores them in the reserve. And when the number of circulating allowances falls below a specified lower limit, the withdrawn allowances are again released into the market. The MSR is designed to advance two main objectives: (1) to reduce the short-term excess in allowances, and (2) to stabilize the ETS in the long term, especially when demand for allowances falls during economic slowdowns. ${ }^{43}$ The European Commission emphasizes that the reserve operates according to pre-defined rules, leaving no discretion to the Commission or to member states in the MSR's implementation. ${ }^{44}$

How effective the MSR will be in ensuring market stability in the ETS remains to be seen. One significant problem, noted by a number of commentators, is that the adjustments made by the MSR are subject to a delay vis-à-vis the behavior of market participants that the adjustments are meant to influence. ${ }^{45}$ Imagine, for instance, that at the end of a given year, the MSR determines that there is a surplus of allowances in the market, which has led to an excessively low price per unit of carbon. In response, the MSR reduces the number of allowances on the market, thereby pushing up the price. By that time, however, it is possible that external economic factors will already have influenced the price in the same direction, thereby leading to an overcorrection. In any case, because the MSR began operating only in 2019, it is still too early to tell whether it will be effective at achieving its goal of stabilizing the ETS market.

\subsection{Undue Political Pressure}

Also undermining the effectiveness of the ETS has been the problem of undue political pressure, especially in the context of the free allocation scheme. One economic analysis found signs that the initial allocation of emission permits had been influenced by lobbying: "Under the EU ETS, governments influenced by special interests made a tradeoff between the quantity of quotas issued and the decision to auction or to grant them for free." 46 The result was that the allocation of permits for 2005 exceeded real $\mathrm{CO}_{2}$ emissions by approximately 100 million tons. ${ }^{47}$

\footnotetext{
${ }^{43}$ Andor et al. (2016), p. 90.

44 "Market Stability Reserve" at the European Commission's Climate Action website (https://ec. europa.eu/clima/policies/ets/reform_en).

${ }^{45}$ See, e.g., Andor et al. (2016), p. 90; and Richstein et al. (2015), p. 3.

${ }^{46}$ Hanoteau (2014), p. 83.

${ }^{47}$ See Kettner et al. (2008), pp. 41-61.
} 
In this way, the lobbying efforts of industries have damaged the effectiveness of the ETS itself. This goes some way toward explaining why the scheme has failed to achieve significant emission reductions.

One interesting question, however, is whether lobbying has continued to damage the effectiveness of the ETS even in Phase 3, where free allocation of permits has been almost completely replaced by an auction scheme. According to one analysis, the shift to an auction-based allocation of permits has not solved the problem but merely shifted the target of lobbying efforts. As part of the auction process in Phase 3 of the ETS, allocations are now made by reference to EU-wide "benchmarks" for emissions per unit of production. ${ }^{48}$ But this seemingly objective process was, in the end, again biased by the power of lobbyists:

Despite the quasi-scientific veneer of technical benchmarks, the decisions on how to define the categories and which criteria to adopt remain subject to the power politics of the industry lobby. Those with access to Brussels decision makers, or to national government departments willing to push their agenda, did best. ${ }^{49}$

The seemingly endless problems and recalibrations of each successive phase of the EU ETS raise a legitimate question: Could it be the case that the problem with the ETS lies not in the details of how it is designed but rather more fundamentally in the very idea of a carbon trading scheme? One potential explanation that merits further attention is the following: The ETS encourages not only companies but also the entire EU public to view greenhouse gas emissions as a problem that one can simply buy one's way out of, while minimizing the impact on the bottom line. Given that the scheme encourages such a profits-based mindset, it is no surprise that companies have felt emboldened to use their lobbying efforts to exploit every facet of the scheme to their maximal advantage. Perhaps, then, what the EU and Switzerland must do in order to effectively reduce greenhouse gas emissions is to focus not on further recalibrations of the ETS scheme but on a fundamental reorientation in how the challenges of climate change and emission reductions are conceived of. The next section will present one possible reorientation of this kind.

\footnotetext{
48 "To set these new standards, the EU split the whole range of industrial goods into 53 categories, such as newsprint, coloured glass bottles, and roof tiles. An emissions limit was defined for each product that was intended to reflect the standards achieved by the most efficient 10 per cent of factories in the EU." Carbon Trade Watch (2011), p. 5; see also Jung (2010).

${ }^{49}$ Carbon Trade Watch (2011), pp. 5-6.
} 


\section{A Human Rights Approach to Climate Change}

\subsection{Link to the Human Rights Approach in the Paris Agreement}

One approach to the problem of climate change that has recently been gaining attention is the human rights approach, ${ }^{50}$ and as has already been noted, the Paris Agreement itself explicitly casts climate change as a human rights issue. It is of course impossible to do full justice to the human rights approach in this short space. So we shall instead focus briefly on how the human rights instrument most relevant to Switzerland and the EU-the European Convention on Human Rights (ECHR) can be seen to generate strong obligations to reduce greenhouse gas emissions.

\subsection{Art. 2 and 8 ECHR and ECtHR Case Law}

The key provisions in the ECHR in connection with climate change are Art. 2 and 8. Art. 2 para. 1 guarantees the right to life, stating, in relevant part, that "[e] veryone's right to life shall be protected by law." And Art. 8 para. 1 states the following: "Everyone has the right to respect for his private and family life, his home and his correspondence." Although not expressly specified in the wording of Art. 8 , the ECtHR's case law has made clear that the provision includes physical and psychological integrity within the scope of its protection. ${ }^{51}$ Thus, while Art. 2 guarantees the right to life, Art. 8 guarantees a certain quality of life. ${ }^{52}$

Art. 2 has not infrequently been invoked by the ECtHR in environmental cases. Much of the Court's Article 2 jurisprudence in the environmental arena deals specifically with industrial hazards and dangerous activities. However, foreseeable environmental disasters can also fall within the scope of the provision. According to the jurisprudence of the ECtHR, a contracting state is obligated under Article 2 to take appropriate measures if there is a real and immediate risk to life and the state is aware of this risk, and this includes risks due to environmental hazards. ${ }^{53}$

Traditionally, Art. 2 and 8 have been understood as negative rights: They prohibit the state from engaging in certain forms of life-threatening conduct (Art. 2) or from

\footnotetext{
${ }^{50}$ For more details, see Hänni (2019), pp. 1-20.

${ }^{51}$ See Hänni (2020), p. 617; Vöneky and Beck (2017), p. 146.

${ }^{52}$ See ECtHR 7 April 2009, No. 6586/03, Brânduşe v. Romania, § 67. For similar provisions in the Swiss Constitution, see Art. 10 and 13.

${ }^{53}$ See, e.g., ECtHR 20 March 2008, Nos. 15339/02, 21166/02, 20058/02, 11673/02 and 15343/02, Budayeva v. Russia, para. 133; ECtHR 24 July 2014, Nos. 60908/11, 62110/11, 62129/11, 62312/ 11 and 62338/11, Brincat v. Malta, paras. 85 and 102; ECtHR 28 February 2012, Nos. 17423/05, 20534/05, 20678/05, 23263/05, 24283/05 and 35673/05, Kolyadenko v. Russia, para. 212; and ECtHR [GC] 30 November 2004, No. 48939/99, Öneryildiz v. Turkey, paras. 89-90.
} 
unjustifiably interfering with an individual's private and family life (Art. 8). In this sense, the state has so-called "negative duties" toward individuals. Negative duties correspond to an individual's rights against state interference. However, the ECtHR has also interpreted Art. 2 and 8 as more than just negative rights. Indeed, it has ruled that a state's failure to protect individuals against adverse environmental effects - even those brought about by private third-parties - can constitute a violation of the right to life, as well as of the right to respect for private and family life. This results in so-called positive duties for member states under the Convention. ${ }^{54}$

For example, in the case of López Ostra, ${ }^{55}$ a complainant (successfully) filed suit on the basis of Art. 8 because of the failure of Spanish authorities to act to prevent fumes that were being emitted from an industrial plant, causing health problems for a number of nearby residents. In a later case, the ECtHR held Italy responsible for failing to provide a functioning garbage collection system, even though there was no proof of a health hazard; the fact that a private company was responsible for the collection did not, in the eyes of the court, exempt Italy from its duty to protect its citizens under Art. $8 ;{ }^{56}$ for the situation tolerated by the state led to a deterioration in the applicants' quality of life, constituting a violation of their right to respect for private life. ${ }^{57}$ The foregoing cases demonstrate that in the area of environmental protection the Court has recognized that the state has a positive duty of protection. In light of this positive duty of protection, states can in principle be held responsible for damages to the quality of life that result from their failure to reduce greenhouse gas emissions sufficiently - as long as this failure can be traced back to the breach of some legal duty.

\subsection{Landmark Judgment in The State of the Netherlands v. The Urgenda Foundation}

The ECtHR itself has not yet ruled on whether the failure to reduce greenhouse gas emissions constitutes a breach of a legal duty-specifically the positive duty of protection-leading to a violation of the Convention. But in December 2019, for the first time, the highest court of a state party to the ECHR - the Supreme Court of the Netherlands - made precisely such a finding in its landmark judgment in the case of The State of the Netherlands (Ministry of Economic Affairs and Climate Policy) v. The Urgenda Foundation. ${ }^{58}$

\footnotetext{
${ }^{54}$ See Hänni (2019), pp. 7-9. For overviews of the ECtHR's jurisprudence on positive obligations, see Sudre (1995), p. 363; Mowbray (2004), Klatt (2011), p. 691.

${ }^{55}$ ECtHR 9 December 1994, No. 16798/90, López Ostra v. Spain, § 51.

${ }^{56}$ ECtHR 10 January 2012, No. 30765/08, Di Sarno and Others v. Italy, §§ 104-108.

${ }^{57}$ See Di Sarno, $\S 108$.

${ }^{58}$ See Hänni (2020), pp. 617-633, for a detailed analysis of the judgment.
} 
One of the most important contributions of the Urgenda judgment is that it develops a powerful link between Art. 2 and 8 ECHR, on the one hand, and international climate change obligations, on the other. It does this via the "common ground" interpretive approach. Thus, quoting from the ECtHR's judgment in the case of Demir and Baykara v. Turkey, ${ }^{59}$ the Supreme Court writes:

The Court, in defining the meaning of terms and notions in the text of the Convention, can and must take into account elements of international law other than the Convention, interpretation of such elements by competent organs, and the practice of European States reflecting their common values. The consensus emerging from specialised international instruments and from the practice of contracting States may constitute a relevant consideration for the Court when it interprets the provisions of the Convention in specific cases. ${ }^{60}$

The common-ground interpretive principle therefore opens the door for the consideration of other elements of international law in the interpretation of Art. 2 and 8 ECHR. Two such elements are especially relevant in the climate-change context.

The first is the so-called "no harm" principle, which was developed in the Trail Smelter arbitration case from the first half of the twentieth century ${ }^{61}$ and is now part of customary international law. According to that principle, states are under an obligation not to allow any activities within their jurisdiction that could cause harm to other states, including individuals in other states. Given that the damages resulting from activities causing global warming are not contained within the states in which such activities take place, the no harm principle can provide a powerful basis for interpreting Art. 2 and 8 to account for damages resulting from climate change.

Second, Article 47 of the International Law Commission's Draft articles on Responsibility of States for Internationally Wrongful Acts provides that when several states are responsible for an internationally wrongful act, each state may be held partially responsible for the resulting harms. In this way, partial fault gives rise to partial responsibility. This provides a way of holding individual countries accountable for their excessive greenhouse gas emissions, independent of whether

\footnotetext{
${ }^{59}$ ECtHR [GC] 12 November 2008, No. 34503/97, para. 85.

${ }^{60}$ Supreme Court of the Netherlands, Supreme Court Judgment, 20 December 2019, The State of the Netherlands (Ministry of Economic Affairs and Climate Policy) and Stichting Urgenda, 19/00135, $\S 5.4 .2$ (English version).

${ }^{61}$ Trail Smelter Case, the United States v. Canada, 1938 and 1941, Report of International Arbitral Awards, vol. III, p. 1905 at p. 1965: "No State has the right to use or permit the use of its territory in such a manner as to cause injury by fumes in or to the territory of another or the properties or person therein, when the case is of serious consequence and the injury is established by clear and convincing evidence."
} 
each country's emissions — taken in isolation—are sufficient to bring about climaterelated harms. $^{62}$

This notion of partial responsibility sets the stage for the next step of the Supreme Court's argument, which is that "Articles 2 and 8 ECHR relating to the risk of climate change should be interpreted in such a way that these provisions oblige the contracting states to do 'their part' to counter that danger." 63 In determining what it means for contracting states to do "their part" in combating climate change, the Supreme Court invokes a firm international consensus that UNFCCC Annex I countries would need to undertake significant reductions in order to avoid the most severe consequences of global warming. The linchpin of the Court's analysis is the IPCC scenario in AR4 in 2007. The Court writes: "This scenario provides for Annex I countries to reduce greenhouse gas emissions by $25 \%$ to $40 \%$ in 2020 and by $80 \%$ to $95 \%$ in 2050, both compared to 1990 emissions." 64 The judgment goes on to marshal a dazzling array of other international sources in support of this significant level of reduction, including the Bali Action Plan, which emerged from the Bali Climate Change Conference in 2007 (COP 13); a resolution passed at the Cancún Climate Change Conference in 2010 (COP 16); another resolution passed at the Durban Climate Change Conference in 2011 (COP 17); and the Doha Climate Change Conference in 2012 (COP 18). ${ }^{65}$ All of these conferences referred back to the IPCC scenario for AR4 as a benchmark for UNFCCC Annex I countries. In addition, the Court also cites the fact that "[s]everal EU bodies - the Council, the Commission and the Parliament - expressed the scientifically supported necessity of reducing emissions by $30 \%$ in 2020 in comparison to 1990."66

In light of this international consensus, the Supreme Court held that the state of the Netherlands, as an Annex I country, has a human-rights based obligation to meet precisely these targets for significant reduction. As stated in the Court's summary of its judgment:

\footnotetext{
All in all, there is a great degree of consensus on the urgent necessity for the Annex I countries to reduce greenhouse gas emissions by at least $25-40 \%$ in 2020 . The consensus on this target must be taken into consideration when interpreting and applying Article 2 and 8 ECHR. The urgent necessity for a reduction of $25-40 \%$ in 2020 also applies to the Netherlands on an individual basis. ${ }^{67}$
}

\footnotetext{
${ }^{62}$ International Law Commission (2001), Art. 47 para. 1. This provision is explicitly invoked at Urgenda, § 5.7.6. See also Nollkaemper et al. (2020), p. 16, Principle 2, which explicitly recognizes shared responsibility for injuries due to "cumulative contributions," in which "the conduct of multiple international persons together results in an injury that none could have caused on their own” (p. 25, para. 5 of Commentary to Principle 2).

${ }^{63}$ Urgenda, $\$ 5.8$.

${ }^{64}$ Urgenda, $\$ 7.2 .1$.

${ }^{65}$ These conferences are referred to at Urgenda, $\S \S 7.2 .2$ and 7.2.3.

${ }^{66}$ Urgenda, \$ 7.2.6.

${ }^{67}$ Urgenda, summary of $\S \S 6.1-7.3 .6$ of the Court's judgment.
} 
It is often said that climate change is a global problem that necessitates a global cooperative solution, rather than a problem that any one country can solve on its own. ${ }^{68}$ Nonetheless, the Court found that a $25-40 \%$ reduction by 2020 was the minimum reduction required for the Netherlands to individually do "its part" in that global effort to reduce greenhouse gas emissions. ${ }^{69}$ Failure to attain this benchmark would, according to the Court, constitute a breach of the Netherlands' obligations under Art. 2 and 8 of the ECHR. ${ }^{70}$

\subsection{Future Prospects of the Human Rights Approach}

It is too early to tell what the implications of the landmark Urgenda judgment will be for other Annex I countries such as Switzerland. This will depend on at least two related factors: (1) whether the highest courts in other European countries will follow the lead of the Supreme Court of the Netherlands in imposing the same requirements on state institutions, and (2) whether the ECtHR will eventually step in to impose such requirements on all, or at least some, Council of Europe states, including Switzerland. ${ }^{71}$

\footnotetext{
${ }^{68}$ Recall the principle of cooperation, Art. 3 para. 5 UNFCCC, discussed in Sect. 2.1.2, herein.

${ }^{69}$ Urgenda, summary of $\S \S 5.6 .1-5.8$ of the Court's judgment.

${ }^{70}$ It is noteworthy that the Supreme Court found that the applicability of Articles 2 and 8 ECHR to the context of climate change was sufficiently clear, such that it explicitly refrains from requesting an advisory opinion from the ECtHR in accordance with Protocol No. 16 of the Convention, which states, in relevant part: "Highest courts and tribunals of a High Contracting Party, as specified in accordance with Article 10, may request the Court to give advisory opinions on questions of principle relating to the interpretation or application of the rights and freedoms defined in the Convention or the protocols thereto" (Art. 1 para. 1). See Urgenda, § 5.6.4.

${ }^{71}$ These two factors are related because the ECtHR often looks to the existence of a "European consensus" among member states in order to determine each state's "margin of appreciation" in state actions and policies that affect human rights fulfillment. On this principle, see Goodwin v. The United Kingdom, no. 28957/95 (2002), §§ 85-86; Tekeli v. Turkey, no. 29865/96 (2004), § 61; Handyside v. The United Kingdom [Plenary], no. 5493/72 (1976), § 48. At least two high-profile cases are now pending before the ECtHR, both involving Switzerland. First, in September 2020, six Portuguese youths filed an application to the Court against 33 states, including Switzerland, claiming violation of the ECHR due to the failure to take sufficient action for the prevention of climate change. A copy of the application in the case is available at https://youth4climatejustice.org. Because of the urgency of the case, the Court has granted it priority consideration under Rule 41 of the Rules of the Court. (Rule 41 states, in relevant part: "In determining the order in which cases are to be dealt with, the Court shall have regard to the importance and urgency of the issues raised on the basis of criteria fixed by it.") The governments of the 33 states have also been ordered to respond to the applicants' claims. See the Court's communication of 13 November 2020 (published 30 November 2020), in the case of Duarte Agostinho and Others v. Portugal and 32 Other States, no. 39371/20, available at http://hudoc.echr.coe.int. And in the second case, mentioned previously (see note 4 above), KlimaSeniorinnen has filed an application against Switzerland, though the Court has not yet issued a communication regarding that application.
} 
Even before these questions are definitively settled, however, this chapter has aimed to provide a basis for further exploration of whether Switzerland's human rights obligations might require it to achieve a far greater reduction in greenhouse gas emissions than participation in the EU's Emissions Trading System and implementation of the $\mathrm{CO}_{2}$ Act would be able to produce on their own. ${ }^{72}$

\section{References}

Andor MA, Frondel M, Sommer S (2016) Reforming the EU emissions trading system: an alternative to the market stability reserve. Intereconomics 51(2):87-93

Arens C, Hermwille L, Kreibich N, Mersmann F, Obergassel W, Ott HE, Wang-Helmreich H (2015) The Paris Agreement: kick-off for true global climate cooperation. Wuppertal Institute for Climate, Environment and Energy, Wuppertal

Bär CC, Brunner U, Casper K, Lustig SH (2018) KlimaSeniorinnen: lessons from the Swiss senior women's case for future climate litigation. J Human Rights Environ 9(2):194-221

Bayer P, Aklin M (2020) The European Union emissions trading system reduced CO2 emissions despite low prices. Proc Natl Acad Sci 117(16):8804-8812

Carbon Trade Watch (2011) EU Emissions Trading System: failing at the third attempt, April 2011. Available at https://corporateeurope.org

Center for Global Development (2015) Developed Countries are Responsible for 79 Percent of Historical Carbon Emissions, 18 August 2015. Available at https://www.cgdev.org

Dehm J (2018) Reflections on Paris: thoughts towards a critical approach to climate law. Revue québécoise de droit international 1(1), Hors-série septembre 2018 - Terre à terre: Environnement et approches critiques du droit, pp 61-91

Ellerman A, Joskow P (2008) The European Union's emissions trading system in perspective. Pew Center on Global Climate Change, Arlington

Ellerman AD, Marcantoniniy C, Zaklan A (2016) The European Union emissions trading system: ten years and counting. Rev Environ Econ Policy 10(1):89-107

European Commission (2008) Emissions trading: 2007 verified emissions from EU ETS businesses. European Commission Press Release, 23 May 2008

European Commission (2020) Communication from the Commission to the European Parliament, the Council, the European Social and Economic Committee and the Committee of the Regions Stepping up Europe's 2030 climate ambition: Investing in a climate-neutral future for the benefit of our people, COM/2020/562 final, 17 September 2020

Federal Office for the Environment (2017) Emissions perspectives of greenhouse gases. Available at https://www.bafu.admin.ch

Federal Office of the Environment (2020) Switzerland's Greenhouse Gas Inventory 1990-2018: National Inventory Report and reporting tables (CRF). Submission of April 2020 under the United Nations Framework Convention on Climate Change and under the Kyoto Protocol. Available at: https://www.bafu.admin.ch

Hänni J (2019) Menschenrechtsverletzungen infolge Klimawandels - Voraussetzungen und Herausforderungen / Dargestellt am Beispiel der EMRK. Europäische Grundrechte-Zeitschrift 46(1-6):1-20

Hänni J (2020) Menschenrechtsschutz in der Klimakrise - Das Leiturteil Urgenda. Europäische Grundrechte-Zeitschrift 47(20-21):616-633

\footnotetext{
${ }^{72}$ For further details on the human rights approach, especially in the context of the European Convention on Human Rights, see Hänni (2019), pp. 1-20.
} 
Hanoteau J (2014) Lobbying for carbon permits in Europe. Recherches économiques de Louvain 80 (1):61-87

International Law Commission (2001) Draft articles on Responsibility of States for Internationally Wrongful Acts, with commentaries, adopted by the International Law Commission at its fiftythird session. Yearbook of the International Law Commission, 2001, vol. II, Part 2

Jung A (2010) Dealing in hot air: the Pitfalls of Europe's new emissions trading system. Spiegel International, 30 December

Kettner C, Köppl K, Schleicher S, Therius G (2008) Stringency and distribution in the EU emissions trading scheme. The 2005 evidence. Clim Policy 8(1):41-61

Klatt M (2011) Positive obligations under the European Convention of Human Rights. Heidelberg J Int Law 71(4):691-718

Köppl K, Kettner C, Kletzan-Slamani D (2011) Price Volatility in Carbon Markets: Why it Matters and How it Can be Managed. Österreichisches Institut für Wirtschaftsforschung, Working Paper No. 409/2011, Wien

McClanahan P (2019) The Bondo Landslide and the Future of Climate Disasters, 19 August 2019. Available at https://www.outsideonline.com

Mexican Interministerial Commission on Climate Change (2011) Fourth National Communication of Mexico to the United Nations Framework Convention on Climate Change, Mexico City

Mowbray A (2004) The development of positive obligations under the European Convention on Human Rights by the European Court of Human Rights. Hart, Oxford

Nollkaemper A, d'Aspremont J, Ahlborn C, Boutin B, Nedeski N, Plakokefalos I (2020) Guiding principles on shared responsibility in international law. Eur J Int Law 31(1):15-72

Rajamani L (2016) Ambition and differentiation in the 2015 Paris Agreement: interpretive possibilities and underlying politics. Int Comp Law Q 65(2):493-514

Richstein JC, Chappin ÉJL, de Vries LJ (2015) The market (in-)stability reserve for EU carbon emission trading: why it might fail and how to improve it. Utilit Policy 35:1-18

Rocha M, Krapp M, Gütschow J, Jeffery L, Hare B, Schaeffer M (2015) Historical responsibility for climate change - from countries emissions to contribution to temperature increase. Climate Analytics, Berlin

Sinclair M (2009) The expensive failure of the European Union emissions trading scheme. Taxpayers Alliance, London. Available at https://www.taxpayersalliance.com

Sudre F (1995) Les "Positive Obligations" dans la Jurisprudence Européenne des Droits de l'Homme. Revue trimestrielle des Droits de l'homme 23:363-384

Stavins RN (2016) Market mechanisms in the Paris climate agreement: international linkage under Article 6.2. In: Stavins RN, Stowe RC (eds) The Paris Agreement and beyond: international climate change policy post-2020. Belfer Center for Science and International Affairs, Cambridge, pp 53-56

Swiss Academies of Arts and Science (2016) Brennpunkt Klima Schweiz. Grundlagen, Folgen und Perspektiven. Swiss Academies Reports, 11/5, Bern

Vöneky S, Beck F (2017) Umweltschutz und Menschenrechte. In: Proelss A (ed) Internationales Umweltrecht. De Gruyter, Berlin, pp 133-181

Julia Hänni is a Justice of the Swiss Federal Supreme Court (Lausanne, Switzerland) and Honorary Professor at the University of St. Gallen Law School (St. Gallen, Switzerland).

Tienmu Ma is an Academic Assistant at the University of Lucerne Faculty of Law (Lucerne, Switzerland). 
Open Access This chapter is licensed under the terms of the Creative Commons Attribution 4.0 International License (http://creativecommons.org/licenses/by/4.0/), which permits use, sharing, adaptation, distribution and reproduction in any medium or format, as long as you give appropriate credit to the original author(s) and the source, provide a link to the Creative Commons license and indicate if changes were made.

The images or other third party material in this chapter are included in the chapter's Creative Commons license, unless indicated otherwise in a credit line to the material. If material is not included in the chapter's Creative Commons license and your intended use is not permitted by statutory regulation or exceeds the permitted use, you will need to obtain permission directly from the copyright holder. 